\title{
Pesma Apps as Android-based Integrated Applications for Mahasantri Pesma KH Mas Mansur UMS
}

\author{
Bisrul Khafid*, Devi Afriyantari Puspa Putri \\ Department of Informatics \\ Universitas Muhammadiyah Surakarta \\ Surakarta \\ *Correspondence: L200150143@ums.ac.id
}

\begin{abstract}
Pesantren Mahasiswa Internasional KH Mas Mansur (Pesma) has a shuttle facility for everyone who lives there. However, the use of the shuttle is not optimal because the ordering procedure still uses manual techniques. It contrasts with the rapid development of industry 4.0 and the mission of Pesma to get digitalization. This paper describes the effort to improve Pesma shuttle bookings by developing an application. The application is built upon the Android Studio 3.5.1 platform and uses Firebase real-time database. The development method implements the System Development Life Cycle (SDLC), Waterfall. The research results in an application called "Pesma Apps" that can be used by staff and mahasantri. Testing the Pesma apps, we obtained sufficiently good results where the black box testing proves that all functions work well. A usability testing using SUS with 30 respondents produces a good result at the level of 72.6, which suggests that the application is accepted.
\end{abstract}

Keywords: android studio, android, pesma apps, shuttle

Article info: submitted March 4, 2020, revised April 15, 2020, accepted April 23, 2020

\section{Introduction}

The rapid changing of globalization nowadays makes the development of Information Technology growing very fast. It makes the use of mobile device increases, especially smartphones, which greatly encourages the effectiveness of an activity. Many people and institutions utilize the development of Information Technology, especially the use of smartphones in the form of android-based applications to facilitate work and daily activities[1]

The demands for the rapid development of information technology requires people to follow these developments. Especially in the education, commerce, transportation and health sectors. In fact, people nowadays want the ease of accessing things through smartphones that most people currently have. [2].

Pesantren Mahasiswa Internasional KH Mas Mansur (Pesma) Univesitas Muhammadiyah Surakarta (UMS) is an institution owned by UMS and under supervision of Lembaga Pengembangan Pondok Al-Islam dan Kemuhammadiyahan (LPPIK) UMS. An active student of UMS who live in Pesma is called Mahasantri. Mahasantri receives some facilities related to education (Language, Religion, and soft skill), sports, and transportation (Shuttle). Shuttle is an operational car that is owned by
Pesma. It can be utilized by directors, staff, employees, and students or Mahasantri. However, the use of shuttle is not optimal yet, because of the ordering procedure that still applies traditional methods. To begin with, mahasantri who wants to book/order the Shuttle is required to confirm to the driver that the unit is ready to use. The authors consider that the process is overcomplicated and is not relevant in the fast-paced era of today. Besides improving the quality of human resources, Pesma also has another mission, namely digitalization. This digitalization is a response of rapid development of industry 4.0 that the purpose is to achieve improvements regarding automation and operational efficiency, as well as effectiveness [3]. However, it can take place in Pesma via smartphones in which there are android-based applications. Therefore, the authors would like to conduct research on existing case studies at Pesma, especially related to Pesma Shuttle bookings.

The output of this research is named "Pesma Apps". Pesma Apps is an integrated application for Mahasantri. However, the authors will examine a smaller scope which focuses on ordering Shuttle. The application is based on Android. The authors create this application using Android Studio and Java Programming. Android mobile OS provides a flexible environment for Android Mobile 
Application Development as the developers can not only make use of Android Java Libraries, but it is also possible to employ normal Java IDEs[4]. However, android can enhance reliability, usability and other features of existing products[5] as we all know that the development of hardware for mobile device is getting better and the performance index is veryhigh than the actual requirements ofthe software configuration. Phone's features are now more dependent on software or application. This paper describes development of Android mobile platform application. Development environment of Windows Mobile and Apple's iPhone are very simplified for mobile applications. Mobile applications give users a quick and reliable user experience. Primary focus of this paper is on the Android architecture based on Linux version 2.6. It is Linux based an open-source mobile phone operating system. Basically Java programming language is used to develop android application. Android SDK provides set of application programming interfaces (APIs.

\section{Method}

The method that used in this research refers to the System Development Life Cycle (SDLC). System Development Life Cycle (SDLC) is a general methodology used to develop information systems. SDLC consists of several phases starting from the planning, analysis, design, implementation and maintenance phases of the system. This SDLC concept underlies various types of software development models to form a framework for planning and controlling information systems. SDLC models that are often used include Waterfall [6].

The authors, in compiling research, were using the SDLC Waterfall model[7]. The Waterfall model has a systematic approach starting from the sequence based on the system's needs and then going to the stages of analysis, design, development, testing or verification and maintenance stages that were implemented in this research.

Requirement Analysis

$$
\begin{aligned}
& \text { Design } \\
& \text { Figure 1. Scheme of Waterfall method } \\
& \text { Requirement Analysis } \\
& \text { The analysis of the equipment required to design the } \\
& \text { Tools and Materials: } \\
& \text { Tools and materials used for design according to the } \\
& \text { Table 1. Macbook Pro used for make programming } \\
& \text { code and Android smartphone with } 5.0 \text { minimum } \\
& \text { version used for build the application }
\end{aligned}
$$

\section{a. Requirement Analysis} Pesma Apps application include:

1) Tools and Materials:
Table 1. Hardware and Software Needs

\begin{tabular}{ll}
\hline \multicolumn{1}{c}{ Hardware } & \multicolumn{1}{c}{ Software } \\
\hline Macbook Pro (Retina, 13- & Android Studio 3.5.1 \\
inch, Early 2013), & \\
Processor 2,6 GHz Intel Core & \\
i5, Memory 8 GB 1600 MHz & \\
DDR3 & \\
Graphics Intel HD Graphics & \\
4000 1536 MB & \\
Smartphone Android OS & Adobe XD \\
USB Cable & Java Programming \\
\hline
\end{tabular}

\section{b. Design}

Design is the initial stage to analyze the shape and design of the application to be created. This design includes a use case diagram that will illustrate the form of a series of interactions between users and activities that are performed in the system.

\section{1) Use Case Diagram}

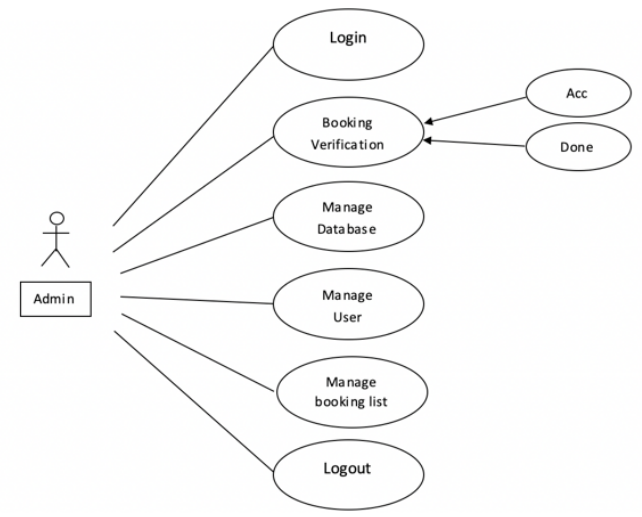

Figure 2. Use Case Admin

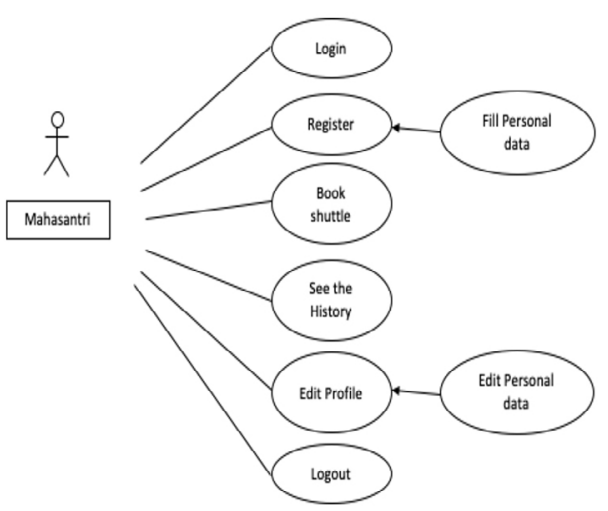

Figure 3. Use Case Mahasantri or User

Use case diagram is applied to model the behavior of information systems that will be created. Use case will describe an activity carried out by the actor. Actors are components involved in using the application. It provides the simplest representation to visualize how actors interact with the admin[8]. Figure 2 describes a use case in which admin can manage the database as 
well as view the user that has been registered, booking list and booking verification. Based on Figure 3, it is observed that user can carry out registration, book shuttle, view the history, and edit user profile.

2) Activity Diagram

The UML Activity Diagram (AD) is an important diagram for modeling the dynamic aspects of a system[9]. Figure 4 describes admin's activity to control the application and to book shuttle.

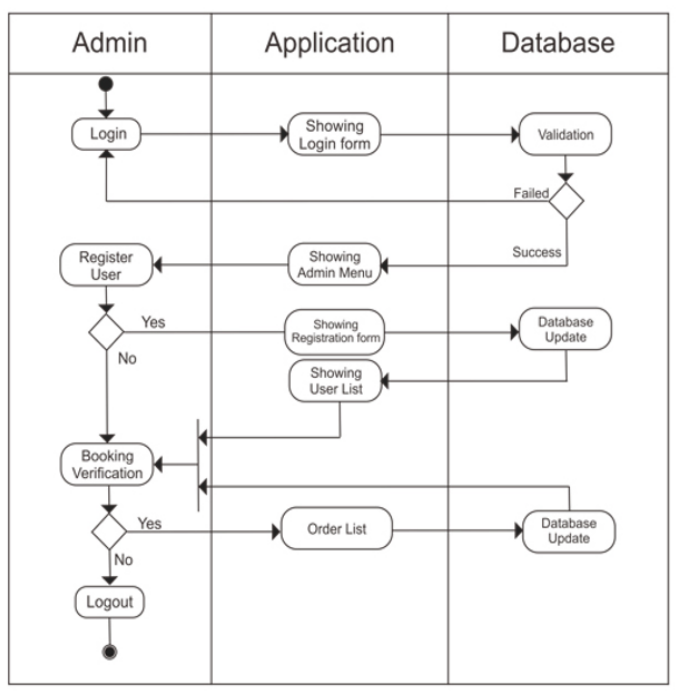

Figure 4. Admin Activity

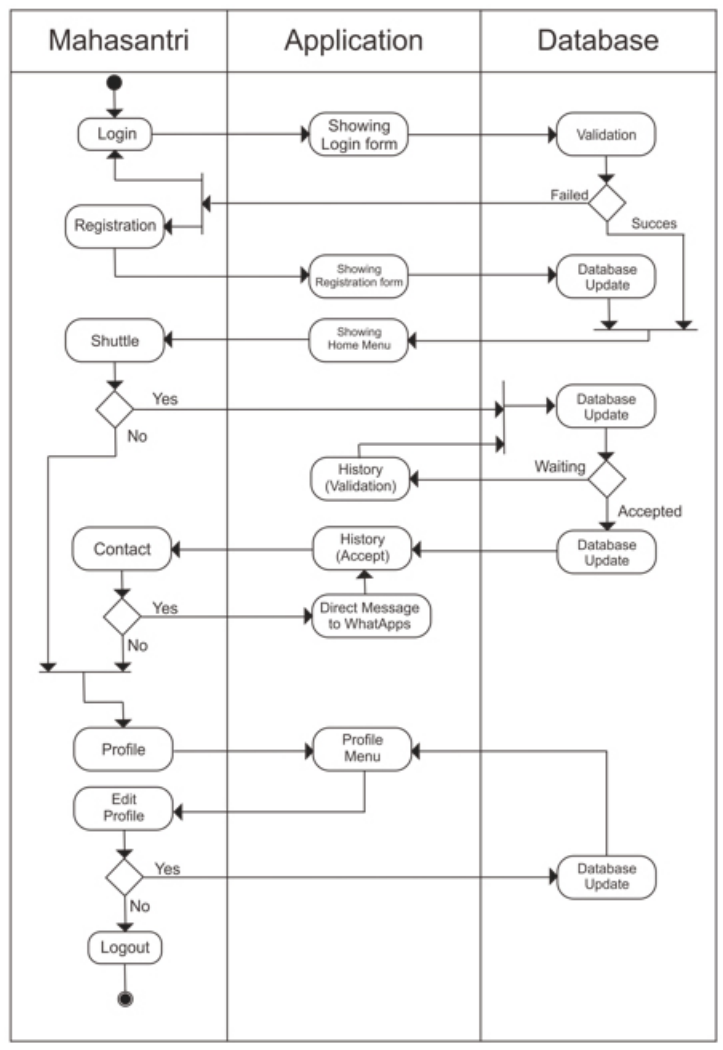

Figure 5. Mahasantri or User Activity
Figure 5 describes the activity that mahasantri can perform several activities such as Registration, Booking shuttle, and the several other commands.

\section{c. Development/Implementation}

The authors started to create applications using Java Programming language to translate the logic expected by the authors with Android Studio Application 3.5.1.

\section{d. Testing}

Testing is an important stage to test the feasibility of an application that has been made and make sure that the application is made in accordance with the initial planning in terms of interface and function. The authors used 2 methods to test applications that are made using the Blackbox testing and System Usability Scale (SUS) because of its versatility, ease of administration, and comparative value[10]data were collected on the usability of applications used on two kinds of mobile platforms-phones and tablets-across two general classes of operating systems, iOS and Android. Over 4 experiments, 3,575 users rated the usability of 10 applications that had been selected based on their popularity, as well as 5 additional applications that users had identified as using frequently. The average SUS rating for the top 10 apps across all platforms was 77.7 , with a nearly 20-point spread (67.7-87.4.

Black Box testing is an application testing in terms of specific functional without testing the design and program code. The point of black box method only tests the functional application and also, it can evaluate valid and invalid entries from users(Putri, 2019). System Usability Scale (SUS), the authors used a questionnaire with a 5-point liker scale, consisting of SD (Strongly Disagree), D (Disagree), N (Neutral), A(Agree), SA (Strongly Agree).

\section{e. Maintenance}

The last phase is the stage of making an application in accordance with the design that has been made. The authors implemented the design using the help of the Android Studio 3.5.1 application using Java programming language and Firebase database because it combines many products with Google's infrastructure and developerfriendly environment[12]. Android Firebase API needed to gain the access to database[13]. The minimum SDK is Android 5.0 version.

\section{Result and Discussion}

a. Application Display Results

1) Introduction to The Initial Menu

The initial menu of the application is the user sign-in display, the option to the admin page, and the button for registration - displayed in Figure 6.

User Sign-in menu Figure 6, appears after splash screen, when the application opened. Users are required to enter the Student Number (NIM) or 
Student Number that has been registered. If the student is not registered yet, the student is required to choose the option register, as shown in figure 7.

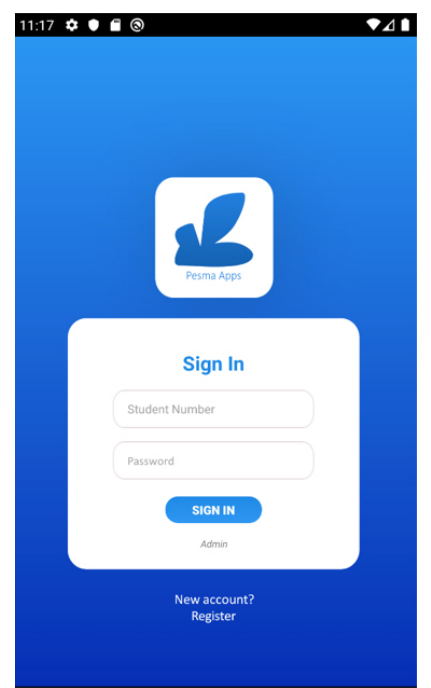

Figure 6. Sign in User

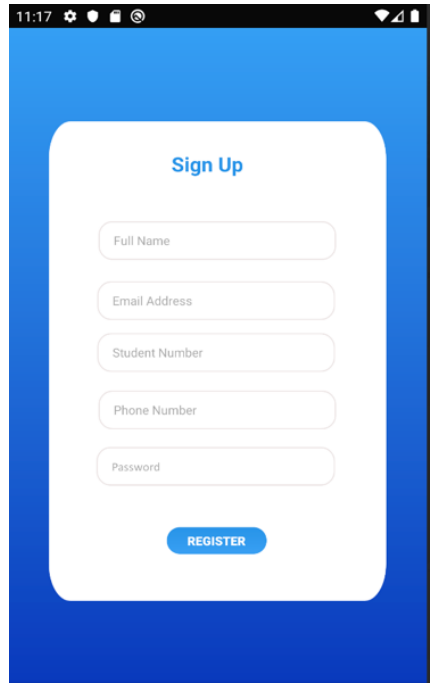

Figure 7. Register User

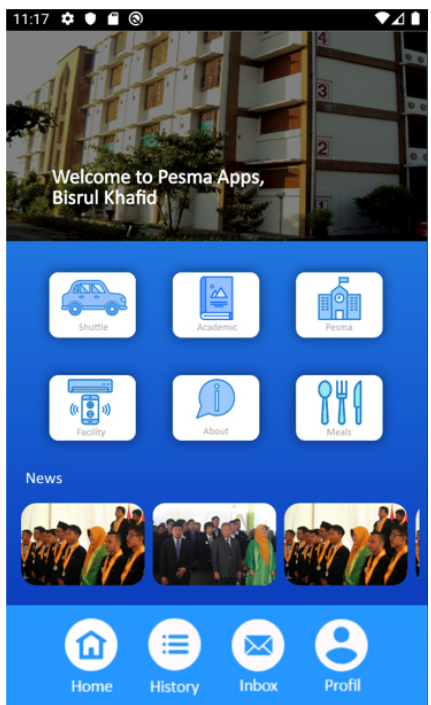

Figure 8. Home
After the registration is conducted successfully. The home page will be displayed, as shown in Figure 8. The home menu shown in Figure 8, displays the main menus that can be accessed by the user including Shuttle, Academic, Pesma, Facility, About, and Meals. This research focuses on Shuttle menu that displayed in Figure 9.

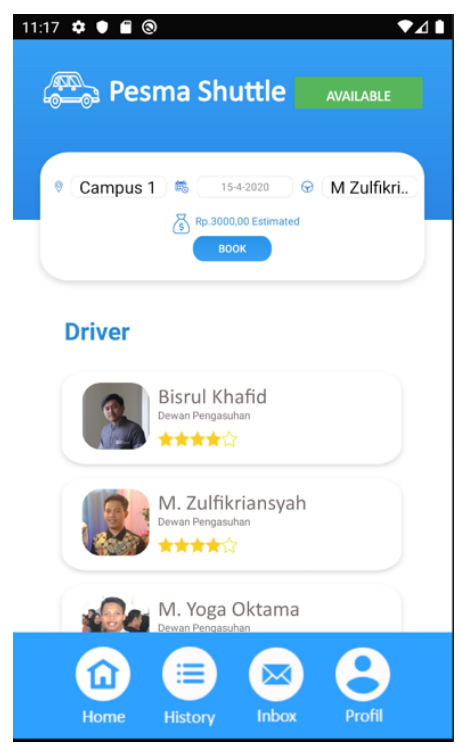

Figure 9. Shuttle Menu

The application provides a function for booking a shuttle. Users are required to choose the desired destination according to the destination list that is available in the application. After selecting a destination, the user chooses the day of the shuttle booking and also picked the available driver. The user presses the book button for the ordering process after deciding the destination selection process, time, and driver. The history menu displays the history of the user transaction - shown in figure 10

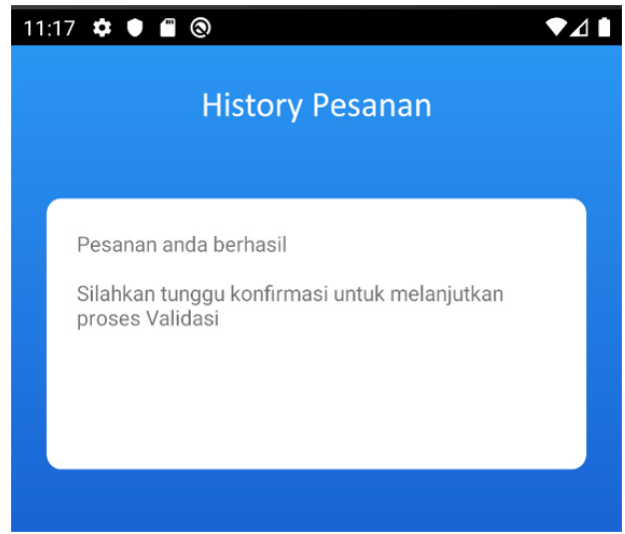

Figure 10. History

2) Admin Menu

Admin menu will be displayed after the admin successfully signs in process. The display of the admin menu is shown in Figure 11. 


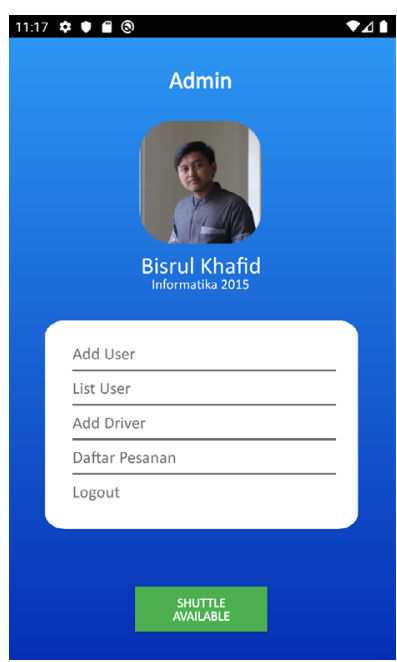

Figure 11. Admin Menu

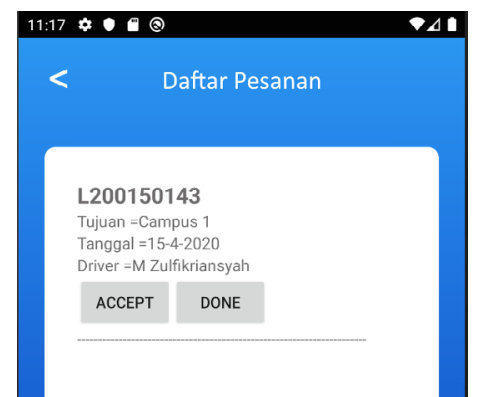

Figure 12. Order List

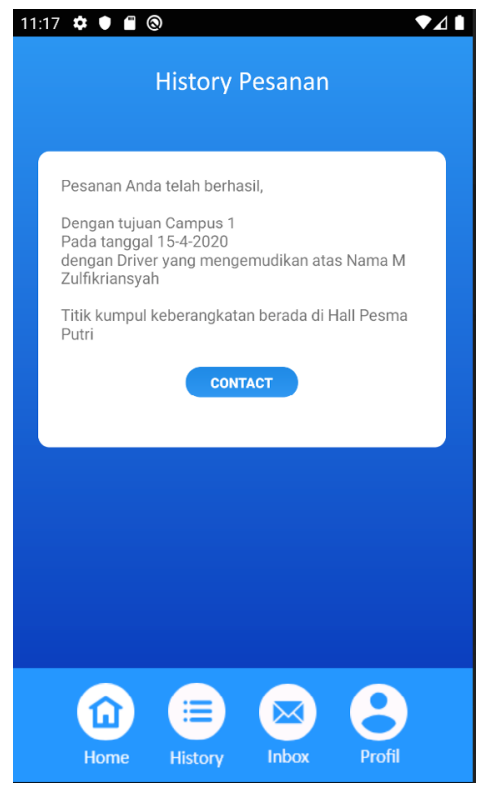

Figure 13. History after Approval

There are several features that can be accessed by the admin, such as add user, user list, order list, logout which can be seen in Figure 11.

The main feature that connects to shuttle booking is shown in Figure 12. It displays a list of incoming orders for being processed by the admin. Also, accept function, which is the approval process for incoming orders. Hence, the user can view the transaction in the history menu after the approval process from the admin.

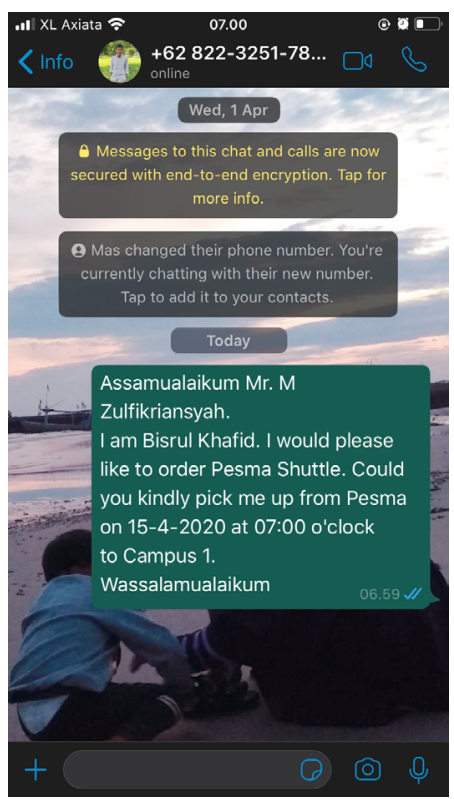

Figure 14. WhatsApp Message

After approval process from the admin, the user is able to view the history after approval, as displayed in Figure 13.

The user can carry out further transactions to the driver by clicking contact button. Then, the display will be directed to WhatsApp or the driver number. It is displayed in Figure 14. The default message from the user to the driver to order the Shuttle.

\section{b. Black Box Test}

The authors employed black box testing to test the application functionally. The purpose of this black box testing method is to find the malfunctions in the program[14]

\section{c. Usability Test}

The usability test used in this study uses the System Usability Scale (SUS) method with 30 respondents from Pesma K.H. Mas Mansur to evaluate usability of Pesma Apps.

The System Usability Scale (SUS) is conducted using a questionnaire that can be used to measure computer system usability according to the user's subjective perspective[15]menunjukkan perlu dilakukannya pengujian usability. Pengujian usability dijalankan untuk mengukur aspek-aspek usability yaitu: efektivitas, efisiensi, dan kepuasan pengguna. Penelitian ini menggunakan kuesioner System Usability Scale (SUS. The question provided, along with the scale, is informed in Table 3. The result of SUS calculation is shown in Table 4. The result is then converted into statistics - informed in Figure 15. 
Table 2. Black Box Testing

\begin{tabular}{|c|c|c|c|c|c|}
\hline No. & $\begin{array}{l}\text { Component } \\
\text { Tested }\end{array}$ & Testing & Input & Output & Result \\
\hline 1 & Sign In Menu & $\begin{array}{l}\text { Form of user sign in } \\
\text { and admin sign in }\end{array}$ & $\begin{array}{l}\text { Student Number / } \\
\text { username and Password } \\
\text { input }\end{array}$ & $\begin{array}{c}\text { Successfully sign in with NIM / username } \\
\text { and password that already registered in the } \\
\text { database }\end{array}$ & Valid \\
\hline 2 & Sign Up Menu & Form of user sign up & Personal data input & $\begin{array}{c}\text { Successfully register using student number } \\
\text { as Mahasantri Pesma }\end{array}$ & Valid \\
\hline \multirow{4}{*}{3} & \multirow{4}{*}{ Shuttle Menu } & Destination drop down & Choosing a destination & $\begin{array}{l}\text { Successfully choose the destination and } \\
\text { show the estimated cost }\end{array}$ & Valid \\
\hline & & Date drop down & Choosing a booking date & Successfully choose the booking date & Valid \\
\hline & & Driver drop down & Choosing a driver & Successfully determine the driver & Valid \\
\hline & & Book button & $\begin{array}{l}\text { Clicking the button for } \\
\text { booking }\end{array}$ & Booking process successful & Valid \\
\hline 4 & History Menu & Contact button & $\begin{array}{l}\text { Clicking the button for } \\
\text { contacting the driver }\end{array}$ & $\begin{array}{l}\text { Successfully open WhatsApp and directly } \\
\text { contact to the driver's number }\end{array}$ & Valid \\
\hline 5 & Edit Profile & Form of profile edit & $\begin{array}{l}\text { Changing the personal } \\
\text { data }\end{array}$ & Successfully change the personal data & Valid \\
\hline \multirow[b]{2}{*}{6} & \multirow[b]{2}{*}{ Admin Menu } & User list & Clicking User List menu & Showing the registered user & Valid \\
\hline & & Order list & $\begin{array}{l}\text { Controlling the booking } \\
\text { list }\end{array}$ & Showing the history menu & Valid \\
\hline
\end{tabular}

Table 3. Table of Information Code and Scale

\begin{tabular}{lrrr}
\hline & Information Code & \\
\hline P1 & I think that I would like to use this system frequently & Strongly Disagree \\
P2 & I found the system unnecessary complex & 2 & Disagree \\
P3 & I thought the system easy to use & Neutral & Agree \\
P4 & I think that I would need the support of a technical person to be able to use this system & 4 & 5 \\
P5 & I found the various functions in this system were well integrated & Strongly Agree \\
P6 & I thought there was too much inconsistency in this system & & \\
P7 & I would imagine that most people would learn to use this system very quickly & \\
P8 & I found the system very cumbersome to use & & \\
P9 & I needed to learn a lot of things before I could get going with this system & \\
P10 &
\end{tabular}

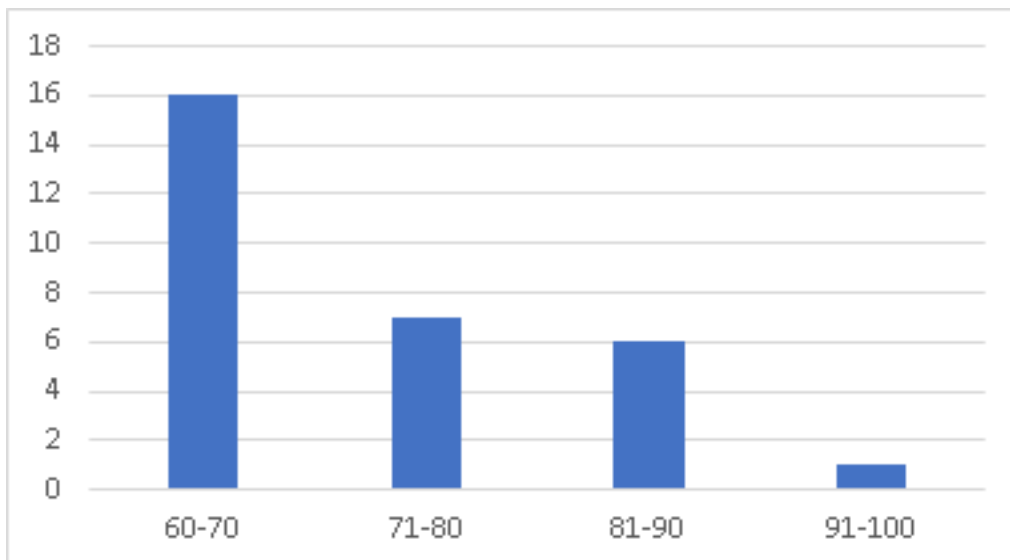

Figure 15. Graphic of SUS Score 
Figure 15 describes the graphic score of SUS Usability test. There are 30 respondents giving scores in 60-70 range, 6 respondents giving scores in 71-80 range, 4 respondents giving scores in 81-90 range, and 1 respondent giving scores in 91-100 range. The complete result of SUS score is informed in Table 4 .

Table 4. Result of SUS Usability Testing

\begin{tabular}{|c|c|c|c|c|c|c|c|c|c|c|c|c|}
\hline \multirow{2}{*}{$\begin{array}{c}\text { No } \\
\text { Respondent }\end{array}$} & \multicolumn{10}{|c|}{ Calculating } & \multirow{2}{*}{ Result } & \multirow{2}{*}{$\begin{array}{c}\text { SUS Score } \\
\text { (Result x 2,5) }\end{array}$} \\
\hline & P1 & P2 & P3 & $\mathbf{P 4}$ & P5 & P6 & P7 & P8 & P9 & P10 & & \\
\hline 1 & 3 & 4 & 4 & 3 & 3 & 4 & 4 & 4 & 4 & 2 & 35 & 87,5 \\
\hline 2 & 3 & 3 & 3 & 3 & 3 & 3 & 3 & 3 & 3 & 3 & 30 & 75 \\
\hline 3 & 3 & 3 & 3 & 1 & 3 & 3 & 3 & 3 & 2 & 2 & 26 & 65 \\
\hline 4 & 2 & 3 & 3 & 4 & 3 & 2 & 4 & 3 & 4 & 3 & 31 & 77,5 \\
\hline 5 & 3 & 2 & 3 & 1 & 3 & 3 & 3 & 3 & 3 & 3 & 27 & 67,5 \\
\hline 6 & 3 & 2 & 2 & 3 & 2 & 2 & 3 & 3 & 3 & 2 & 25 & 62,5 \\
\hline 7 & 2 & 3 & 3 & 3 & 1 & 3 & 3 & 3 & 3 & 3 & 27 & 67,5 \\
\hline 8 & 3 & 3 & 3 & 2 & 3 & 3 & 3 & 3 & 3 & 2 & 28 & 70 \\
\hline 9 & 3 & 3 & 3 & 3 & 4 & 3 & 4 & 4 & 4 & 4 & 35 & 87,5 \\
\hline 10 & 3 & 3 & 3 & 3 & 2 & 3 & 3 & 2 & 3 & 2 & 27 & 67,5 \\
\hline 11 & 4 & 3 & 3 & 3 & 4 & 4 & 3 & 4 & 4 & 3 & 35 & 87,5 \\
\hline 12 & 2 & 3 & 2 & 3 & 2 & 3 & 2 & 3 & 3 & 3 & 26 & 65 \\
\hline 13 & 1 & 2 & 2 & 4 & 1 & 2 & 3 & 3 & 3 & 3 & 24 & 60 \\
\hline 14 & 3 & 3 & 4 & 4 & 3 & 4 & 4 & 3 & 3 & 3 & 34 & 85 \\
\hline 15 & 3 & 3 & 3 & 3 & 1 & 3 & 3 & 1 & 3 & 3 & 26 & 65 \\
\hline 16 & 2 & 2 & 3 & 3 & 1 & 2 & 3 & 2 & 3 & 3 & 24 & 60 \\
\hline 17 & 3 & 3 & 3 & 2 & 3 & 3 & 3 & 3 & 3 & 2 & 28 & 70 \\
\hline 18 & 4 & 2 & 4 & 3 & 2 & 3 & 3 & 3 & 3 & 3 & 30 & 75 \\
\hline 19 & 3 & 2 & 3 & 2 & 2 & 2 & 3 & 2 & 3 & 2 & 24 & 60 \\
\hline 20 & 2 & 3 & 3 & 3 & 2 & 3 & 3 & 3 & 2 & 3 & 27 & 67,5 \\
\hline 21 & 2 & 2 & 3 & 3 & 2 & 3 & 3 & 3 & 3 & 3 & 27 & 67,5 \\
\hline 22 & 4 & 3 & 3 & 1 & 3 & 3 & 4 & 3 & 3 & 3 & 30 & 75 \\
\hline 23 & 3 & 3 & 3 & 3 & 2 & 2 & 2 & 3 & 2 & 1 & 24 & 60 \\
\hline 24 & 4 & 0 & 4 & 0 & 4 & 3 & 4 & 4 & 4 & 0 & 27 & 67,5 \\
\hline 25 & 3 & 4 & 4 & 4 & 4 & 4 & 4 & 4 & 4 & 4 & 39 & 97,5 \\
\hline 26 & 4 & 3 & 3 & 3 & 4 & 3 & 4 & 3 & 4 & 3 & 34 & 85 \\
\hline 27 & 3 & 3 & 3 & 3 & 3 & 3 & 3 & 3 & 3 & 3 & 30 & 75 \\
\hline 28 & 3 & 3 & 3 & 3 & 1 & 3 & 3 & 3 & 4 & 3 & 29 & 72,5 \\
\hline 29 & 4 & 3 & 3 & 3 & 3 & 3 & 4 & 3 & 4 & 3 & 33 & 82,5 \\
\hline 30 & 3 & 3 & 3 & 3 & 1 & 3 & 3 & 3 & 4 & 3 & 29 & 72,5 \\
\hline \multicolumn{12}{|c|}{ SUS Result } & 2177,5 \\
\hline
\end{tabular}

The results of the SUS usability test calculation shown in Table 4, produce a total SUS score of 2535. The average value of the total SUS score earned from Equation (1).

Average Score $=\sum_{i=1}^{n} \frac{x}{N}$

$\sqrt{x_{i}}=$ Total score SUS
$N=$ Total respondent

The Average Score of SUS $=\frac{2177,5}{30}=72,5833333$

The Average score of SUS is 72,583333 - earned from equation (1), thus concluded that Pesma Apps shows Good results and Acceptable, based on SUS score ranking taken from [16] with research about SUS Usability testing that can be observed in Figure 10. 


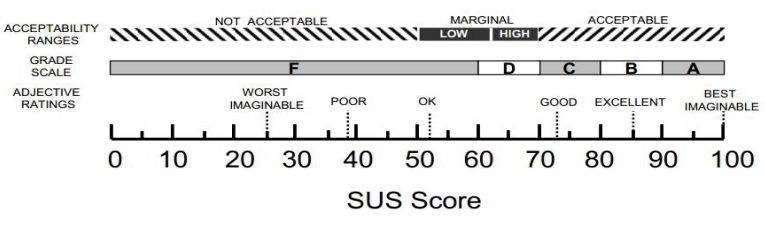

Figure 16. SUS Score Ranking

\section{Conclusion}

Based on the experiment, it is concluded that the application created from this research is ready to use. The name of the application is "Pesma Apps". Pesma Apps is made to facilitate students in ordering Pesma shuttle. This application provides the information regarding shuttle that can be ordered. It can also show the available routes that can be ordered by mahasantri - along with the estimated costs that must be paid by mahasantri.

The black box evaluation the Pesma Apps produces good results. The functions of the application results in valid results meaning the whole process of the application works well. The usability testing using SUS results in a good score of 72.6. Therefore, it can be stated that the application is acceptable and it can be declared that this application is well-conducted and this research can be further developed to make it better, for example about database management and academic learning system.

\section{References}

[1] X. (2013). P. A. S. I. A. P. P. A. 1-10. Sinsuw, AliciaSinsuw, A., \& Najoan and X. Najoan, "Prototipe Aplikasi Sistem Informasi Akademik Pada Perangkat Android,” pp. 1-10, 2013.

[2] S. Listiani, W. S. Sari, S. Informasi, F. Ilmu, K. Universitas, and D. Nuswantoro, "Perancangan Aplikasi Mobile E-Commerce Berbasis," Sist. Inf., no. 5, p. 2, 2014.

[3] J. Nagy, J. Oláh, E. Erdei, D. Máté, and J. Popp, "The role and impact of industry 4.0 and the internet of things on the business strategy of the value chain-the case of hungary," Sustain., vol. 10, no. 10, 2018, doi: 10.3390/su10103491.

[4] G. Goggin, "Google phone rising: The Android and the politics of open source," Continuum (N. Y)., vol. 26, no. 5, pp. 741-752, 2012, doi: 10.1080/10304312.2012.706462.

[5] A. Singh, S. Sharma, and S. Singh, "Android Application Development using Android Studio and PHP Framework," Int. J. Comput. Appl. Recent Trends Futur. Prospect. Eng. Manag. Technol., pp. 975-8887, 2016.

[6] R. Susanto and A. D. Andriana, "Perbandingan Model Waterfall Dan Prototyping Untuk Pengembangan Sistem Informasi," Maj. Ilm. UNIKOM, vol. 14, no. 1, pp. 41-46, 2016, doi: 10.34010/miu.v14i1.174.
[7] S. M. Muyasaroh and E. Sudarmilah, "Game Edukasi Mitigasi Bencana Kebakaran Berbasis Android," PROtek J. Ilm. Tek. Elektro, vol. 6, no. 1, pp. 49-55, 2019, doi: 10.33387/protk. v6i1.1029.

[8] N. A. Rahman and N. A. M. Zin, "Visualizing Requirements using Use Case Diagram and Diagram 0 for Compound Information System," J. Math. Comput. Sci., vol. 3, no. 1, pp. 34-38, 2018.

[9] T. Ahmad, J. Iqbal, A. Ashraf, D. Truscan, and I. Porres, "Model-based testing using UML activity diagrams: A systematic mapping study," Comput. Sci. Rev., vol. 33, pp. 98-112, 2019, doi: 10.1016/j.cosrev.2019.07.001.

[10] P. Kortum and M. Sorber, "Measuring the Usability of Mobile Applications for Phones and Tablets," Int. J. Hum. Comput. Interact., vol. 31, no. 8, pp. 518-529, 2015, doi: 10.1080/10447318.2015.1064658.

[11] D. A. Puspa Putri, "Rancang Bangun Media Pembelajaran Bahasa Arab Untuk Anak Usia Dini Berbasis Android," Technol. J. Ilm., vol. 10, no. 3, p. 156, 2019, doi: 10.31602/tji.v10i3.2230.

[12] A. Shilpa, "International Journal of Trend in Scientific Research and Development (IJTSRD ) Smart Drip Irrigation System," pp. 1560-1565, 2018.

[13] A. R. Wiratno and K. Hastuti, "Implementation of Firebase Realtime Database to Track BRT Trans Semarang," Sci. J. Informatics, vol. 4, no. 2, pp. 95-103, 2017, doi: 10.15294/sji. v4i2.10829.

[14] D. K. Baroroh and R. Ramadhan, "Perancangan Alat Bantu Analisis Rapid Entire Body Assessment (REBA) Berbasis Aplikasi Android," J. Nas. Tek. Elektro dan Teknol. Inf., vol. 7, no. 3, pp. 266-272, 2018, doi: 10.22146/jnteti. v7i3.434.

[15] I. H. N. Aprilia, P. I. Santoso, and R. Ferdiana, "Pengujian Usability Website Menggunakan System Usability Scale Website Usability Testing using System Usability Scale," J. IPTEK-KOM, vol. 17, no. 1, pp. 31-38, 2015.

[16] C. Panagopoulos, S. A. Bioassist, E. Kalatha, P. Tsanakas, and I. Maglogiannis, "Evaluation of a Mobile Home Care Platform Evaluation of a Mobile Home Care Platform Lessons Learned and Practical Guidelines," no. May 2016, 2015, doi: 10.1007/978-3-319-26005-1. 